\title{
Forest Wetland Area and the Forest Sector Economy in the U.S. South
}

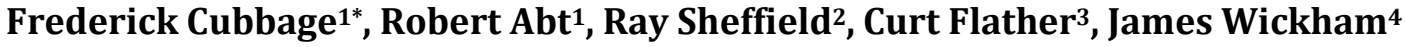 \\ ${ }^{1}$ North Carolina State University, Raleigh, North Carolina, USA \\ ${ }^{2}$ Consultant, Asheville, North Carolina, USA \\ ${ }^{3}$ USDA Forest Service, Fort Collins, Colorado, USA \\ ${ }^{4}$ U.S Environmental Protection Agency, Research Triangle Park, North Carolina, USA \\ Email: *fred_cubbage@ncsu.edu
}

How to cite this paper: Cubbage, F., Abt, R., Sheffield, R., Flather, C., \& Wickham, J. (2018). Forest Wetland Area and the Forest Sector Economy in the U.S. South. Open Journal of Forestry, 8, 409-428. https://doi.org/10.4236/ojf.2018.83026

Received: March 23, 2018

Accepted: July 27, 2018

Published: July 30, 2018

Copyright ( 92018 by authors and Scientific Research Publishing Inc. This work is licensed under the Creative Commons Attribution International License (CC BY 4.0).

http://creativecommons.org/licenses/by/4.0/

(c) (i) Open Access

\begin{abstract}
This article reviews current data on forest wetlands and their economic contributions in the South, ranging from Texas to Virginia. Based on USDA Forest Service Forest Inventory and Analysis (FIA) data, the wetland category comprised $17.7 \%$ of timber land area on all private and public lands in the South. This included 4.25 million ha of hydric sites; 0.77 million ha mesic wet; 9.55 million ha mesic, with only seasonal access; for a total of 14.57 million ha. The Natural Resource Inventory (NRI) for 2012 on private lands estimated that there were 14.71 million ha forested wetlands, which comprised $17.7 \%$ of all forested private forest area. The 2015 National Land Cover Data for the South estimated that there were 17.8 million ha of woody wetlands, which comprised $8 \%$ to $12 \%$ of the southern land area, and there were also 4.45 million ha of emergent herbaceous sites. About $10 \%$ of the southern timber forest sector would be based on harvests from wetland forests economy ( $\$ 455$ million per year), while the $17.7 \%$ of wetland land area would provide a proportional share of the annual nontimber forest products ( $\$ 44$ million) and payments for ecosystem services ( $\$ 134$ million). Wetlands also provide important nontimber forest products, and ecosystem services, which are beginning to develop active private and public markets.
\end{abstract}

\section{Keywords}

Forest, Wetlands, Area, Economics, Valuation

\section{Introduction}

Forested wetlands provide important market and nonmarket goods and services in the South. This paper provides a review of forested wetland area data and the 
forest products economy, focusing on timber values and economic contributions, also including an overview of nontimber forest products values and direct ecosystem services payments that wetlands may contribute to the region. Determining the precise area of forest wetlands in the South is difficult, since it depends on dynamic changes in the actual biophysical extent of wetlands; the objectives and methods used by several different federal organizations to measure that extent; and changing national definitions, policies, and court decisions dictating the definition.

The key forested wetland area and economic questions stem from the forested (or bottomland) definition and area. Wetlands may depend on ecological characteristics; federal agency definitions of jurisdictional wetlands based on hydrology, soils, vegetation, and various types of stocks (inventory, sinks, or pools) and flows of goods or services. Wetlands may produce annual or periodic flows and harvests, market and nonmarket values and prices, timber, nontimber products, or ecological and environmental services. We examine three principal sources that provide wetlands definitions and estimates to bracket the likely area of forested wetlands in the South.

Then we summarize secondary data on the annual market value of timber harvests, the forest products industry economic contributions, sales of nontimber forest products, and direct market payments received for forest ecosystem services in the South. We did not consider indirect economic or multiplier effects of forest products industries, nontimber products, or nonmarket values of ecosystem services, which are more complex and imprecise valuation questions.

\section{Forest Wetland Definition and Area}

For here, we classify southern forests as those covering the 13 southern states ranging from Texas to Virginia (Figure 1). This includes 216.5 million hectares (535 million acres) of total land area; 99.2 million ha (245 million ac) of forest land; and 85.0 million ha (210 million ac) of timber land that could provide commercial timber harvests. Forest ownership includes 59.5 million ha (60\%) private non-corporate, 26.3 million ha (27\%) private corporate, and 13.35 million ha (13\%) public owners (Oswalt et al., 2014).

A widely agreed upon definition of the term wetland has been absent since the neologism was adopted (see Tiner (2016) for a review of the term's history and current definitions). In part, a single definition has not been widely adopted because of the numerous aspects from which it might arise (e.g., ecology, soil science, hydrology, legal, jurisdictional). For example, a mud flat might satisfy wetland criteria for a soil scientist or hydrologist but not for an ecologist because mud flats are generally devoid of vegetation. The seemingly countless jurisdictional-specific definitions provided by Tiner (2016) document the variety factors that are considered in identifying what constitutes a wetland.

Within the United States, the Federal Water Pollution Control Act (FWPCA) Amendments of 1972, now termed the Clean Water Act (CWA) after its amendments in 1977, have served as an organizing force for setting standards on 


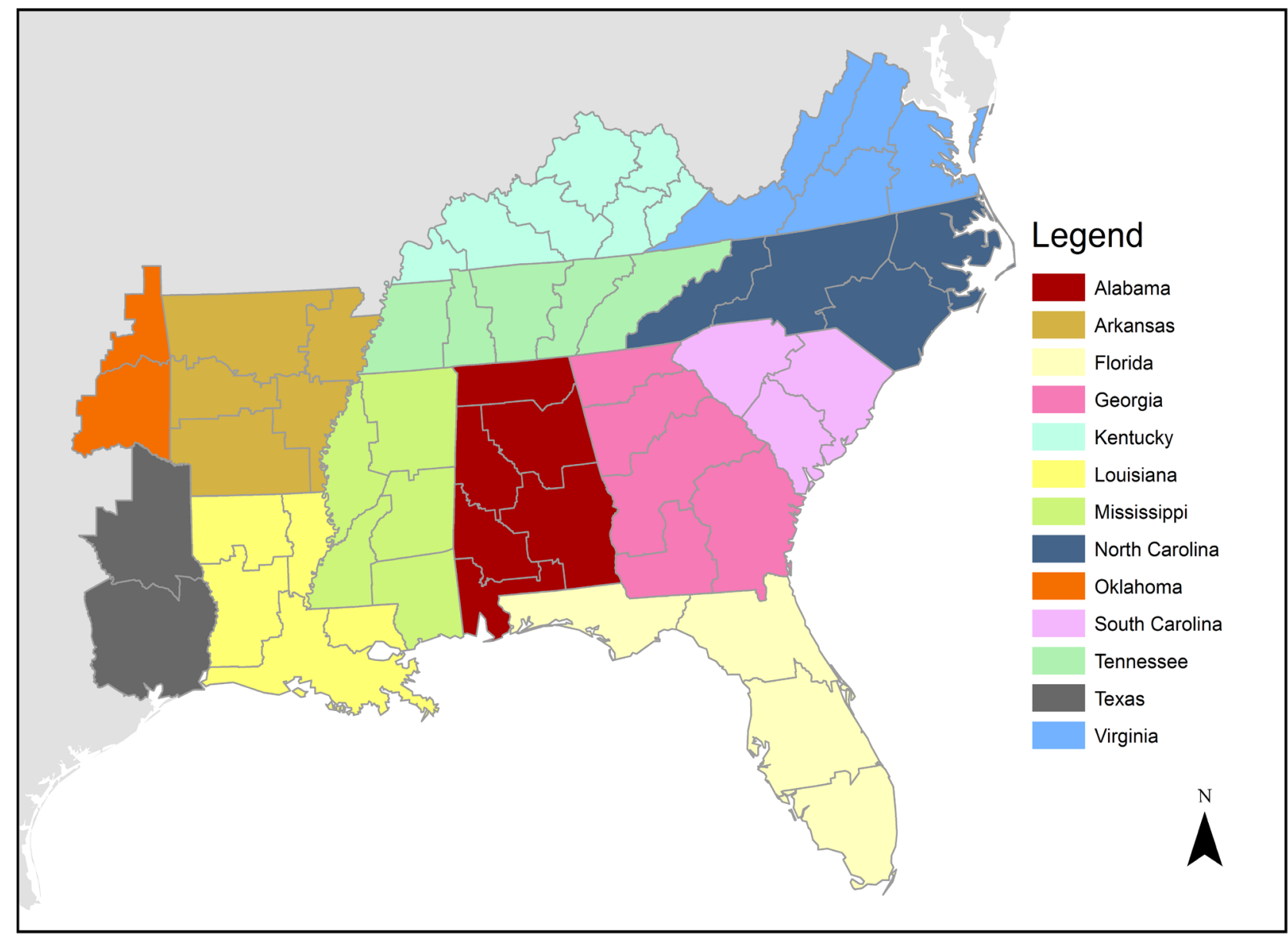

Figure 1. Thirteen states comprising the U.S.A. south forest region.

what constitutes a wetland (Cubbage et al., 2017). This definition has become increasingly important, since land that is classified as a "federal" wetland, whether on public or private land, is subject to varying levels of regulation, permits, and control of forest, agriculture, and development practices. In brief, Section 404 of the FWPCA/Clean Water Act definition of a wetland is that they are "Those areas that are inundated or saturated by surface or ground water at a frequency and duration sufficient to support, and that under normal circumstances do support, a prevalence of vegetation typically adapted for life in saturated soil conditions. Wetlands generally include swamps, marshes, bogs, and similar areas." The FWPCA/Clean Water Act definition includes the three main criteria that are regarded as distinguishing wetlands from uplands (Tiner, 2016). The typical three criteria for wetland determinations are:

- Hydrology-recurrent soil saturation or inundation during the growing season, e.g. for $5 \%-12 \%$ of the period, or about 14 consecutive days

- Hydrophytic plants-species that are adapted to life in saturated soils, e.g. obligate species

- Hydric soils-soils that formed under anaerobic and reducing conditions, e.g. mottled, smell like rotten eggs 


\section{Wetland Areas}

Each of the three federal organizations that classify wetlands has derived somewhat different area estimates. We summarize the amount of forested wetland area estimates based on the USDA Forest Service Forest Inventory and Analysis (FIA) data, the USDA Soil Conservation Service National Resource Inventory (NRI) data, and the USDI Geological Survey National Land Cover Data (NLCD). The FIA data for the South classes their forest plots that cover all ownerships with various characteristics that serve as proxies for wetlands. First, they class each site surveyed as a land type, such as the wetlands that consist of hydric sites, or wet flood plains/bottomlands. They also classify wetlands by operability class, with either year round water or seasonal access. The USDA Natural Resource Inventory (NRI) analysis estimates land classes on private lands. The National Land Cover Database provides a point estimate of woody wetlands, also covering all lands in the U.S.

\subsection{USDA Forest Inventory and Analysis (FIA) Data}

The Forest Service FIA data provides a comprehensive survey of forest areas in the United States (https://www.fia.fs.fed.us/tools-data/), with a number of breakdowns that can be used to classify forest areas as wet, providing a good proxy for those areas with formal federal wetlands designation. We obtained and screened the FIA data for the South to identify forests that would be likely to have the three key federal wetlands hydrology characteristics listed above, with forest vegetation management types as well, although soils data were not available.

The FIA survey crews categorize forest land data in management types based on land use classes-these classes may call even cut-over land as forests if they appear to be regenerating and coming back as forests in the future. There are various classes of forest land in timber land, with "forest" being the broadest-covering all lands covered at least $10 \%$ with trees, and having a minimum area of 1 acre $(0.4 \mathrm{ha})$. Timber land is more relevant in determining market values of forest land, and reflects land that is capable of producing crops of industrial wood and not withdrawn (e.g., under a reserved or protected land designation) from timber utilization or administrative regulation (Oswalt et al., 2014).

We performed this data screening for timber land in the U.S. South in three phases, such that the survey plot had to have some degree (ranging from the wettest to the driest stand types) of wetland characteristics as defined by FIA (USDA Forest Service 2018a) and paraphrased here as applied to our southern forest data screening:

- Phase 1: Hydric sites: Abundant or overabundant moisture all year; swamps, bogs, drains, bays, pocosins, beaver and cypress ponds

- Phase 2: Mesic, wet: Flatwoods; narrow floodplains/bottomlands; broad floodplains/bottomlands; areas with year-round water problems

- Phase 3: Mesic plus: Seasonal limited access due to water conditions in wet 
weather; Mixed wet and dry, multi-channeled streams punctuated with dry islands

As of 2016, there were 82.5 million ha (204 million ac) of total timber land included in the current FIA South data set that we used as summarized in Table 1. Upland hardwood management types comprised 31.6 million ha (38\% of the area); oak-pine 7.3 million ha (9\%); natural pine 12.9 million ha (16\%); pine plantation 18.2 million ha (22\%); and bottomland hardwoods 12.6 million ha (15\%).

As one would expect, the southern hydric timber land area as identified in Phase 1 - 4,262,208 ha-was concentrated in the bottomland hardwood area, but not found only there, nor were all bottomland hardwoods hydric with abundant moisture all year long (Table 1). For bottomland hardwoods, 3.2 million ha were classified as hydric sites, or $25 \%$ of the total bottomland hardwood type. Upland hardwood had 0.21 million ha of hydric sites, but only $0.7 \%$ of their total area. Oak pine had 0.42 million ha of hydric sites, and $5.7 \%$ of their total management type. Natural pine management type had 0.40 million ha (3.1\%) in hydric sites. Pine plantation had only 0.05 million ha as very wet hydric sites $(0.3 \%$ of their type). Bottomland hardwood type forests did comprise $75 \%$ of all hydric sites.

Southern mesic timber land, with year around water problems, consisted of 782,945 ha. This Phase was concentrated even more in the bottomland hardwood forest types, with $87 \%$ of all of these types. For bottomland hardwoods, 681,246 ha were classified as mesic wet sites, or $5.4 \%$ of the total bottomland hardwood type. Upland hardwood had 66,393 ha of mesic wet sites, or only $0.2 \%$ of their total area. Oak pine had 21,922 ha of mesic wet sites, and $0.3 \%$ of their total management type. Natural pine had 10,333 ha $(0.1 \%)$ of their management type. Pine plantation had only 3050 ha as mesic wet sites $(0.02 \%$ of their management type).

Table 1. Forest Inventory and Analysis (FIA) wetland forest areas based on a 3 phase hydric estimation filter for the U.S. South by state and forest management type, 2016.

\begin{tabular}{|c|c|c|c|c|c|c|c|}
\hline \multirow{2}{*}{ Management Type } & \multirow{2}{*}{$\begin{array}{c}\text { Total Timber Land Area } \\
\mathrm{Ha}\end{array}$} & \multicolumn{2}{|c|}{ Hydric Physiology } & \multicolumn{2}{|c|}{ Mesic, Year-Round-Water } & \multicolumn{2}{|c|}{ Mesic, Seasonal Water } \\
\hline & & $\mathrm{Ha}$ & $\%$ of Mgt. Type & $\mathrm{Ha}$ & $\%$ of Mgt. Type & $\mathrm{Ha}$ & $\%$ of Mgt. Type \\
\hline Pine Plantation & $18,192,048$ & 54,157 & $0.3 \%$ & 3050 & $0.0 \%$ & $1,239,128$ & $6.8 \%$ \\
\hline Natural Pine & $12,861,298$ & 396,225 & $3.1 \%$ & 10,333 & $0.1 \%$ & 746,032 & $5.8 \%$ \\
\hline Oak-pine & $7,276,108$ & 415,818 & $5.7 \%$ & 21,922 & $0.3 \%$ & 564,202 & $7.8 \%$ \\
\hline Upland Hardwood & $31,584,595$ & 213,064 & $0.7 \%$ & 66,393 & $0.2 \%$ & $1,481,869$ & $4.7 \%$ \\
\hline Bottomland Hardwood & $12,556,678$ & $3,182,944$ & $25.3 \%$ & 681,246 & $5.4 \%$ & $5,545,509$ & $44.2 \%$ \\
\hline All Types (ha) & $82,470,727$ & $4,262,208$ & $5.2 \%$ & 782,945 & $0.9 \%$ & $9,576,740$ & $11.6 \%$ \\
\hline All Types (ac) & $203,702,695$ & $10,527,653$ & $5.2 \%$ & $1,933,874$ & $0.9 \%$ & $23,654,548$ & $11.6 \%$ \\
\hline
\end{tabular}

Drawn from USDA Forest Service (2018a) FIA data base, (https://www.fia.fs.fed.us/tools-data/). Note: 1 ha $=2.47$ ac. 
Phase 3 of the data screens, southern mesic timber land, with seasonal access, consisted of a much larger area of 9,576,740 ha. This Phase was less concentrated in the bottomland hardwood forest types, which had $58 \%$ of all of these types. For bottomland hardwoods, 5.55 million ha were classified as mesic/seasonal access sites, or $44.2 \%$ of the total bottomland hardwood type. Upland hardwood had 1.5 million ha of mesic/seasonal access sites, or $4.7 \%$ of their total area. Oak pine had 0.56 million ha of these sites, and $7.8 \%$ of their total management type. Natural pine had 0.75 million ha of mesic/seasonal access lands, or $5.8 \%$ of their management type. Pine plantation had 1.2 million ha of mesic/seasonal access sites- $6.8 \%$ of their management type.

The area of all three FIA data screens for forests ranging from hydric sites with year-round water to mesic sites with seasonal access totaled 14,615,975 ha, or $17.7 \%$ of all southern forests (Figure 2). As expected, bottomland hardwoods dominated this total area, with 9.4 million ha, or $64 \%$ of the total wetland types, but it was not the only forest type with some type of wetland characteristics. Upland hardwood forests had 1.76 million ha, or $12 \%$ of the total area in these three forest wetland types. Oak pine forests had 1.0 million ha, or $6.8 \%$ of the total in these three forest wetland types. Natural pine forests had 1.15 million ha, or $7.9 \%$ of the total in these three forest wetland types. Planted pine forests had 1.29 million ha, or $8.9 \%$ of the total in these three forest wetland types.

As a percentage of their total forest area by management type, bottomland forests had $75 \%$ classified in the three wetland phases. Upland forests had $6 \%$; oak

Total $=14,621,892$ ha; $17.7 \%$ of all Timber Land

8

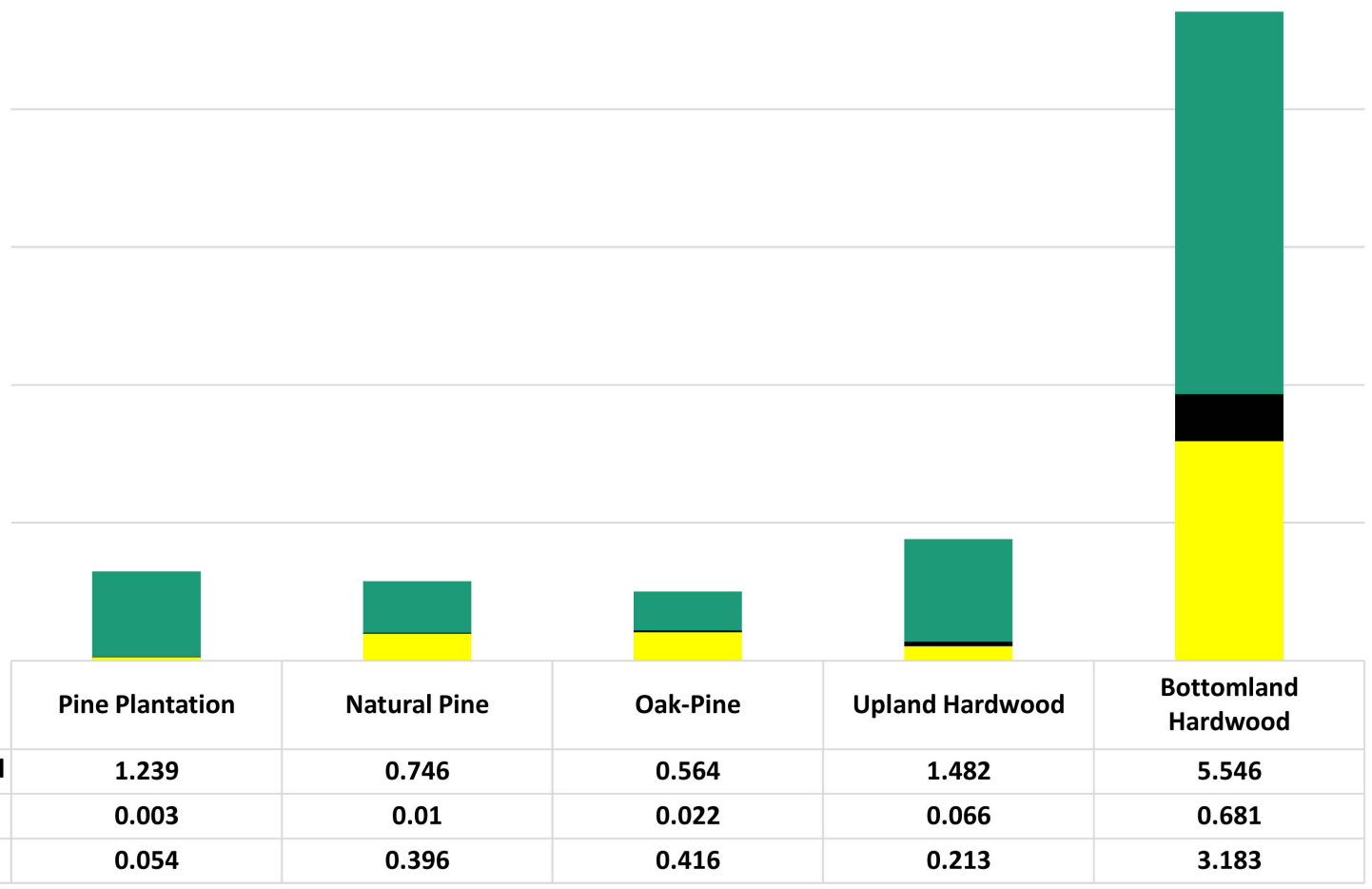

Figure 2. Cumulative FIA southern timber land wetland areas, 2016 (Million Hectares). 
pine 14\%; natural pine 9\%; and planted pine $7 \%$ that fell in the wetland screens. So overall, note that not all bottomland hardwoods are likely to be wetlands, and that even upland forests and pine plantations are apt to have some areas with that vegetation and physiographic type that do include wetland areas based on hydrology.

Figure 3 shows the mesic wet forest types - the largest pine wetland areas-for natural and planted pine by state as classified by FIA. In general, the data indicate that the South Central states seem to have a much greater area of pine forests that lie in mesic wet areas than the Southeast, with more than twice as much wet pine areas. This seems counterintuitive given the vast pine forests and wet areas from Georgia to North Carolina, so perhaps the field crews were more chary calling areas as wetlands in the eastern South than in the western South.

\subsection{Southern Wetland Area, Private Lands, Natural Resource Inventory}

The USDA Natural Resource Inventory (NRI) also measures land type as part of its periodic survey of private lands in the United States

(https://www.nrcs.usda.gov/wps/portal/nrcs/main/national/technical/nra/nri/).

For reference, in the U.S. South, private forests comprise $87 \%$ of all timber land (Oswalt et al., 2014). Cubbage \& Flather (1993) examined wetlands status with NRI data previously, which we update here. The most recent data available are for 2012, which can be compared to the 1992 data, again spanning from Texas to Virginia (Table 2). As the table shows, the wetland area has been pretty consistent since the 1990s, and the strict federal no net loss of wetlands policy since then would suggest that was likely to continue in the 2000s as well, unless that policy is reversed or not enforced.

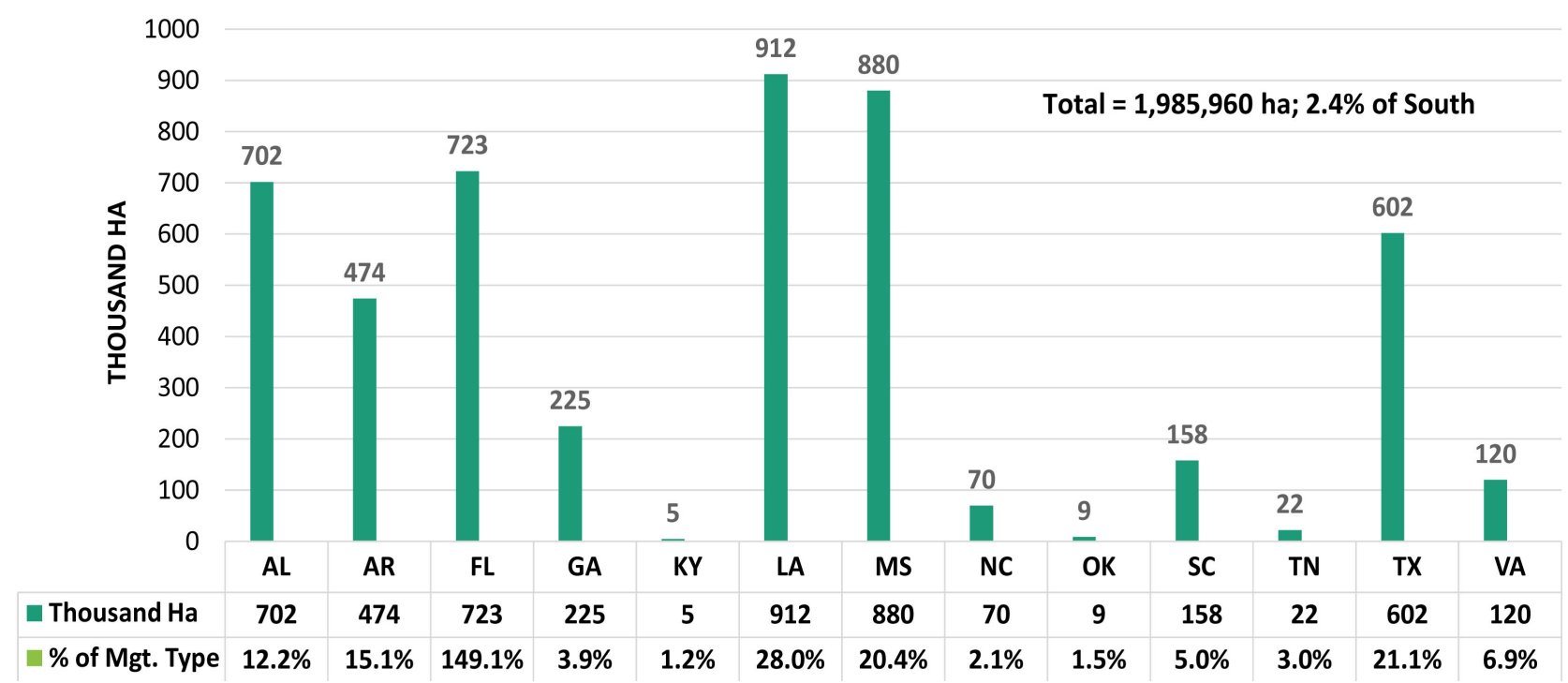

Figure 3. FIA Mesic seasonal access pine types by State, 2016 (Thousand Hectares). 
Table 2. USDA natural resource inventory of Palustrine forest wetland areas in the south by state, 1992 to 2012 (Thousand $\mathrm{Ha}$ ).

\begin{tabular}{ccccccc}
\hline State/Year & 1992 & 1997 & 2002 & 2007 & 2012 & Change, 1997-2012 \\
\hline Alabama & 1216.2 & 1221.7 & 1231.0 & 1229.5 & 1232.2 & 16.1 \\
Arkansas & 1038.8 & 1036.5 & 1049.3 & 1053.3 & 1054.5 & 15.7 \\
Florida & 2007.0 & 1999.6 & 2016.3 & 2006.4 & 2012.1 & 5.1 \\
Georgia & 2304.7 & 2279.3 & 2261.3 & 2250.9 & 2242.4 & -62.3 \\
Kentucky & 86.6 & 86.4 & 85.6 & 86.1 & 86.0 & -0.5 \\
Louisiana & 1945.0 & 1957.0 & 1959.0 & 1957.5 & 1957.7 & 12.7 \\
Mississippi & 1415.4 & 1418.7 & 1442.9 & 1443.3 & 1448.2 & 32.8 \\
North Carolina & 1790.3 & 1784.5 & 1766.9 & 1754.5 & 1749.7 & -40.5 \\
Oklahoma & 46.7 & 49.7 & 45.9 & 45.9 & 45.8 & -0.9 \\
South Carolina & 1286.3 & 1279.5 & 1264.1 & 1255.1 & 1249.3 & -36.9 \\
Tennessee & 176.0 & 177.5 & 180.6 & 179.4 & 181.7 & 5.6 \\
Texas & 984.6 & 1016.7 & 1015.3 & 1011.8 & 1006.7 & 22.0 \\
Virginia & 462.0 & 451.3 & 447.4 & 443.6 & 440.1 & -21.9 \\
South Total & $14,759.6$ & $14,758.4$ & $14,765.6$ & $14,717.1$ & $14,706.6$ & -53.1 \\
\hline
\end{tabular}

Drawn from USDA NRI data base,

(https://www.nrcs.usda.gov/wps/portal/nrcs/main/national/technical/nra/nri/). Note: 1 ha $=2.47$ ac.

The NRI data indicate that there were 21.6 million ha of palustrine and estuarine wetlands in 2012; of that, 14.7 million ha (68\%) were forested (Table 2). Southern palustrine/estuarine wetlands would include inland, nontidal wetlands with trees, shrubs, and emergent vegetation as well as tidal wetlands with similar vegetation definitions. Some of the estuarine wetlands could include forest types, and some palustrine wetlands could include vegetation smaller than trees. Thus Table 2 summarizes only the data for forested wetlands.

Of the total of 14.7 million ha of forested wetlands in the South, Georgia (2.2 million ha), Florida (2.0 million ha), Louisiana (1.95 million ha), and North Carolina (1.75 million ha) had the largest area in 2012, stemming from their large areas in the coastal plain of the South. The more mountainous states of Kentucky and Tennessee, as well as drier Oklahoma, had less than 0.2 million ha of forested wetlands. Most other southern states still had more than 1.0 million ha of forested wetlands ( 2.5 million ac), which is substantial.

According to the 2012 NRI, there was a relatively small loss of forested wetlands, of about 53,100 ha from 1992 to 2012 , or $0.4 \%$. The forested wetlands class of 14.71 million ha ( 36.3 million ac) is quite close to the FIA data estimate of 14.61 million ha of hydric and mesic wet forest land area in the South. The NRI data excludes public lands, so probably underestimates the total area of forested wetlands somewhat, but a large share of federal southern public lands do fall in the mountains, which have few wetlands. 


\subsection{Wetlands, National Land Cover Data}

The National Land Cover Database (NLCD) (https://www.mrlc.gov/) maps land cover for the United States using Landsat satellite and other ancillary data (Homer et al., 2015). Forested wetlands are common and widely dispersed throughout the region based on NLCD maps (Table 3 and Figure 4). The figure class labels are

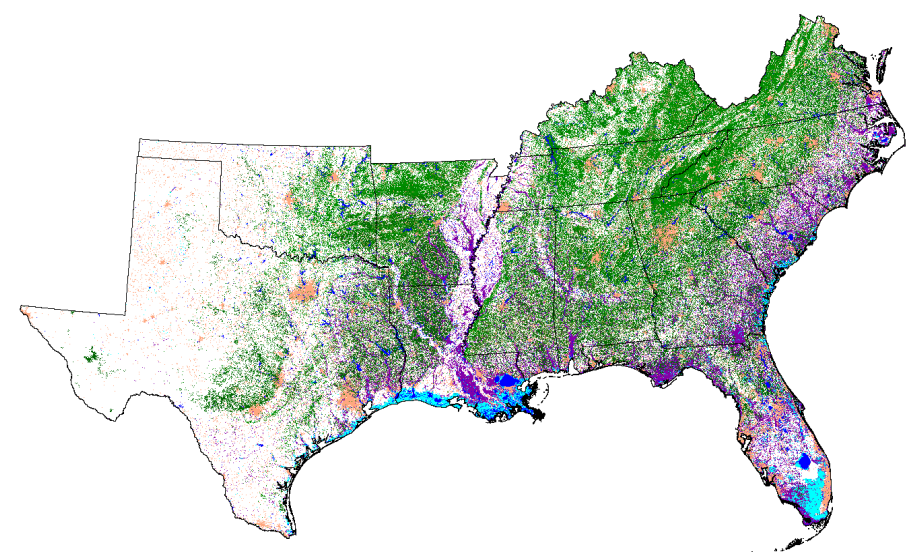

Orange $=$ urban; green $=$ upland forest; purple $=$ woody wetland $($ wet forest $) ;$ cyan $=$ emergent wet land; blue $=$ water. The other classes (agriculture, grassland, shrubland, barren) are not colored.

Figure 4. National land cover data map with forest wetland areas, 2015.

Table 3. National land cover forest and wetland data by state, 2015.

\begin{tabular}{|c|c|c|c|c|c|}
\hline State & $\begin{array}{c}\text { Total Area } \\
\left(\mathrm{m}^{2}\right)\end{array}$ & $\begin{array}{c}\% \\
\text { Forest }\end{array}$ & $\begin{array}{l}\% \text { Wet } \\
\text { Forest }\end{array}$ & $\begin{array}{l}\text { Total Forest } \\
\qquad\left(\mathrm{m}^{2}\right)\end{array}$ & $\begin{array}{c}\text { Total Wet } \\
\text { Forest }\left(\mathrm{m}^{2}\right)\end{array}$ \\
\hline Alabama & $133,767,165,600$ & 58 & 7 & $77,712,498,900$ & $9,958,687,200$ \\
\hline Arkansas & $137,732,292,900$ & 53 & 8 & $72,427,229,100$ & $11,281,618,800$ \\
\hline Florida & $146,735,834,400$ & 41 & 24 & $60,528,393,900$ & $35,418,807,900$ \\
\hline Georgia & $152,307,513,000$ & 55 & 14 & $84,520,463,400$ & $20,818,739,700$ \\
\hline Kentucky & $104,657,864,400$ & 53 & 1 & $55,091,835,000$ & $844,201,800$ \\
\hline Louisiana & $121,086,503,100$ & 41 & 20 & $49,473,464,400$ & $23,803,763,400$ \\
\hline Mississippi & $123,475,359,600$ & 51 & 14 & $63,298,069,200$ & $16,709,824,800$ \\
\hline North Carolina & $127,739,958,300$ & 53 & 13 & $68,083,551,900$ & $16,582,857,300$ \\
\hline Oklahoma & $181,040,856,300$ & 21 & 0 & $38,451,024,900$ & $819,306,000$ \\
\hline South Carolina & $80,120,871,000$ & 55 & 19 & $43,674,390,000$ & $15,263,081,100$ \\
\hline Tennessee & $109,148,771,700$ & 53 & 3 & $57,404,357,100$ & $3,070,488,600$ \\
\hline Texas & $685,707,185,700$ & 13 & 3 & $90,903,663,000$ & $19,574,094,600$ \\
\hline Virginia & $103,546,566,000$ & 60 & 4 & $62,495,493,300$ & $4,654,788,300$ \\
\hline South Total & $2,207,066,742,000$ & 37 & 8 & $824,064,434,100$ & $178,800,259,500$ \\
\hline South w/o TX\&OK & $1,340,318,700,000$ & 52 & 12 & $694,709,746,200$ & $158,406,858,900$ \\
\hline South (acres) & $545,366,192$ & & & $203,626,322$ & $44,181,544$ \\
\hline South w/o TX \& OK (acres) & $331,192,751$ & & & $171,662,778$ & $39,142,335$ \\
\hline
\end{tabular}

Drawn from NLCD data base (https://www.mrlc.gov/). Note: $1 \mathrm{~m}^{2}=0.0001$ ha; $10,000 \mathrm{~m}^{2}=1$ ha; 1 ha $=2.47$ ac. 
based on land cover, so cut-over forest may be identified as shrubland and grassland rather than the parcel's land use (e.g., forest). The NLCD classification includes four classes of urban development, three classes of upland forest, two classes of agriculture and wetland, and one class each for barren, water, shrubland, and grassland (https://www.mrlc.gov/nlcd11_leg.php).

The NLCD data base provides a larger estimate of forested wetlands in the South than the FIA data did, at 17.9 million ha (44.1 million ac) for the same 13 states. However, the NLCD data indicate that Texas has the largest forest area in the South, which must include a lot of area that is not timber land by FIA definitions, and Oklahoma is also one of the largest forested wetland states, which certainly differs from FIA. If one were to remove these optimistic data points, the NLCD forest wetland area would decrease to 15.8 million ha (39.1 million ac), which seems more aligned with the other two federal government data sources. This discrepancy between NLCD and FIA/NRI is also notable when one measures the share of forest land in the South. Without Texas and Oklahoma, the NLCD would indicate that forest cover types comprise 52\% of the South; which is similar to FIA. With Texas and Oklahoma, which have vast areas of rangelands, forests comprise only $37 \%$ of all land covers, which seems unrepresentative of the rest of the forested South from east Texas to Virginia. However, the NLCD data do seem to be more consistent than the FIA data with what one would expect across the South by state, with a fairly logical distribution of wetland types by size of state and proximity to wet coasts, regardless if they are in the West South or East South (Figure 5).

\section{Forest Products, Nontimber Products, and Ecosystem Service Payments}

Timber harvests and wood based manufacturing are a major part of the southern economies, and wetlands forests contribute a modest share of those harvests and value added. In addition, forests are producing an increasing amount of nontimber forest products, and provide a variety of ecosystem services, and some of those may generate direct payments to monetize those previously nonmarket values. This section summarizes aggregate southern timber, manufacturing, nontimber, and ecosystem service payments that are available in the literature.

As noted before, we only summarized data on the annual market value of timber harvests, the forest products industry economic contributions, sales of nontimber forest products, and direct market payments received for forest ecosystem services in the South. We did not consider indirect or multiplier effects of forest products industries, nontimber products, or nonmarket values of ecosystem services. Each of these broader effects of forest economies are important, but become much more complex and unique to different regions and different methods of estimation, and indeed considerable scientific debate in the case of ecosystem services. Thus we focused strictly on an "apple-to-apple" comparison of the measurable market sales revenue or direct payments that actually were received and estimated for southern wetland forests. 


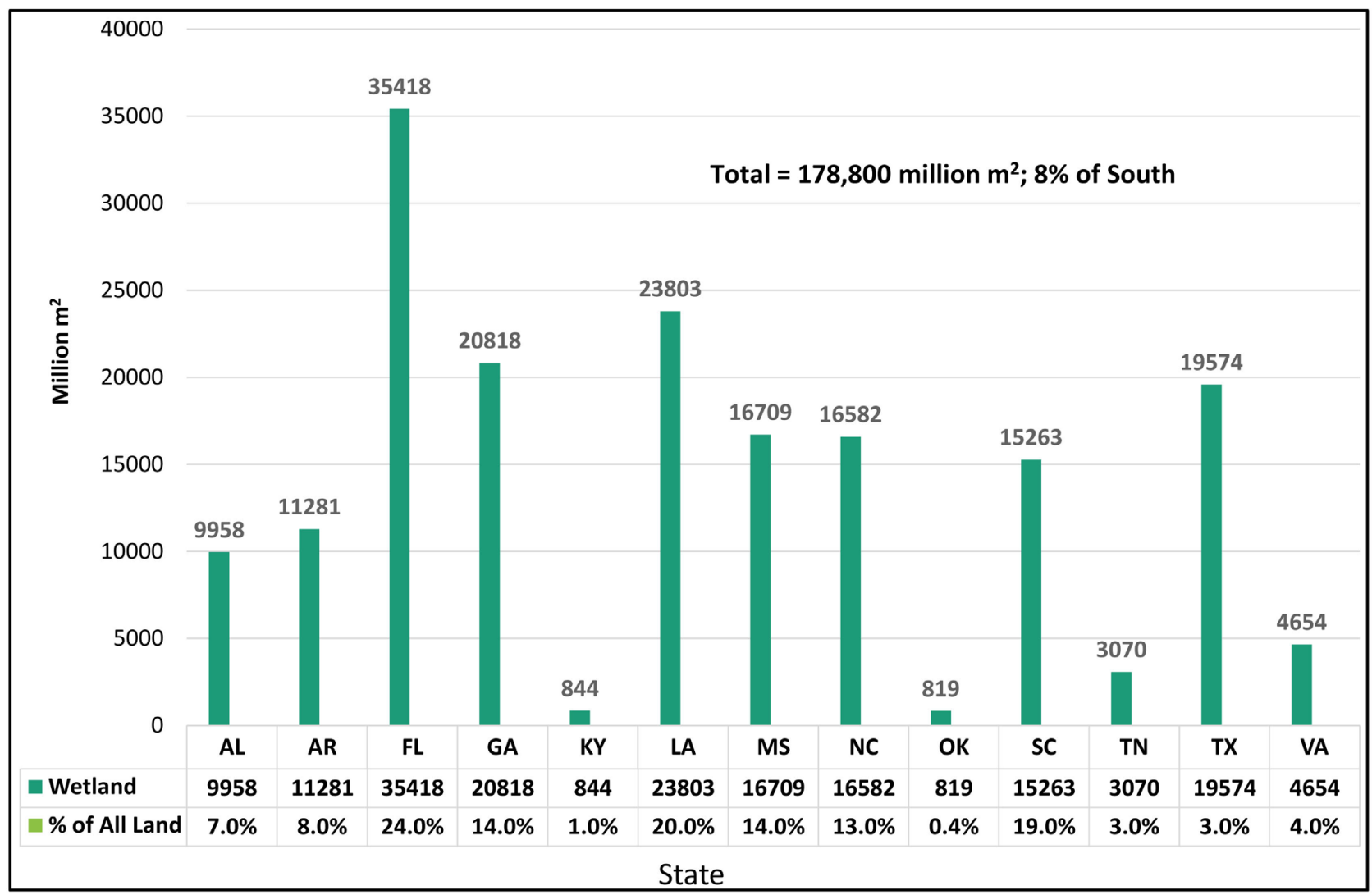

Figure 5. Total National Land Cover (NLCD) wet forest area by state (Million $\mathrm{m}^{2} /$ Percent of all land).

\subsection{Forest Products Economic Contributions}

As of 2012, the South had a stock of 359 billion cubic feet of timber inventory, consisting of 136 billion cubic feet of softwoods and 222 billion cubic feet of hardwoods. The "flows" from this stock were annual timber harvests and removals for 2011 of 8.0 billion cubic feet, with 5.3 billion cubic feet of softwoods and 2.7 billion cubic feet of hardwoods. This was a decrease from 9.8 billion cubic feet in 2006, before the economic recession of 2008.

One could calculate a growth to removals ratio for these timber volumes as 1.6:1 for pine and 1.92 for hardwoods. Bottomland hardwoods actually have a lower growth to removal ration, at $1.51: 1$, but are thus still growing $50 \%$ more volume each year than is being removed. Softwoods had an inventory to removal ratio for these timber volumes as 25:1, and it was 82:1 for hardwoods. This can be interpreted as the implicit rotation age of 25 and 82 years without growth for the two major species groups. Thus both softwoods and hardwoods had annual growth greater than annual removals, which would infer that there is a large supply of timber in the foreseeable future.

It also is worth noting that lowland hardwoods had a very high concentration of volumes in the oldest age classes of 50 years or older (Figure 6), with about half the total area. For the lowland hardwood age class in the South, there were 14.3 million acres ( 5.79 million ha) in the 0 - 50 year old age classes, and 12.7 


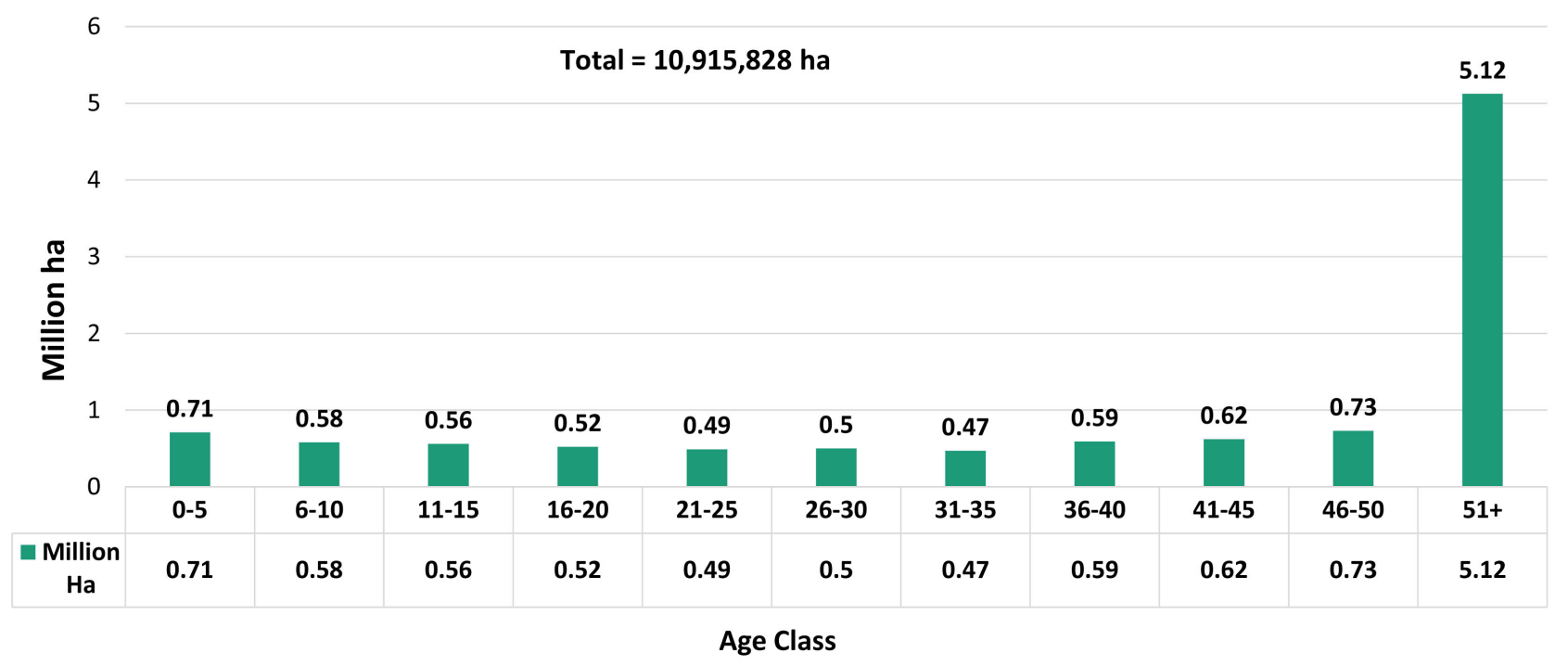

Figure 6. Age class distribution of lowland hardwood stands in the U.S. south.

million acres (5.12 million ha) in the 50+ age class ( $47 \%$ of all lowland hardwoods). This indicates a surprising lack of diversity on lowland hardwood stands. Upland hardwoods were actually worse, with $53 \%$ on the oldest age class of 50+ years. In contrast, planted pines had no reported volumes in the $46-50$ or $50+$ age classes. Natural pines had $24 \%$ older than 50 years of age; oak-pine had $36 \%$.

The forest products industry economic contributions included those from forests, timber production, and processing of solid wood, wood furniture, and paper products. Employment in all these sectors in 2009 totaled 470,000 persons, which was $0.84 \%$ of the South total employment. Their gross industrial output was $\$ 133$ billion, $1.62 \%$ of the South total. Wages and salaries were $\$ 26$ billion; $0.96 \%$ South Total. Total value added was $\$ 43$ billion, $0.98 \%$ South total (Dahal et al., 2015).

Economic contributions were similar in 2011 although total direct employment was still 473,000 persons, and value added was $\$ 46$ billion. Indirect effects from forest products would almost double those, with 1 million employees and $\$ 87$ billion of value added. As shown in Figure 7, the forest products sector contributions to each state total economy ranged from a low of $0.7 \%$ in Florida to about 5\% in Arkansas (Brandeis \& Hodges, 2015).

One also can make rough estimates of the share of bottomland hardwoods as a component of the total timber harvests in the South using the FIA data set and average blended pulpwood (50\%) and sawtimber $(50 \%)$ prices of $\$ 0.60$ per cubic foot ( $\$ 21$ per cubic meter) for both softwood and hardwoods, drawn from Timber Mart-South (2016) prices of about $\$ 25$ per ton for sawtimber and $\$ 8$ per ton for pulpwood, or either softwood or hardwood species. Bottomlands comprised $28 \%$ of all hardwoods, which would be 0.964 billion cubic feet of harvests. At the price of $\$ 0.60$ per cubic feet, this would translate into an annual bottomland harvest value of $\$ 450$ million. For comparison, the total hardwood price for 2.7 


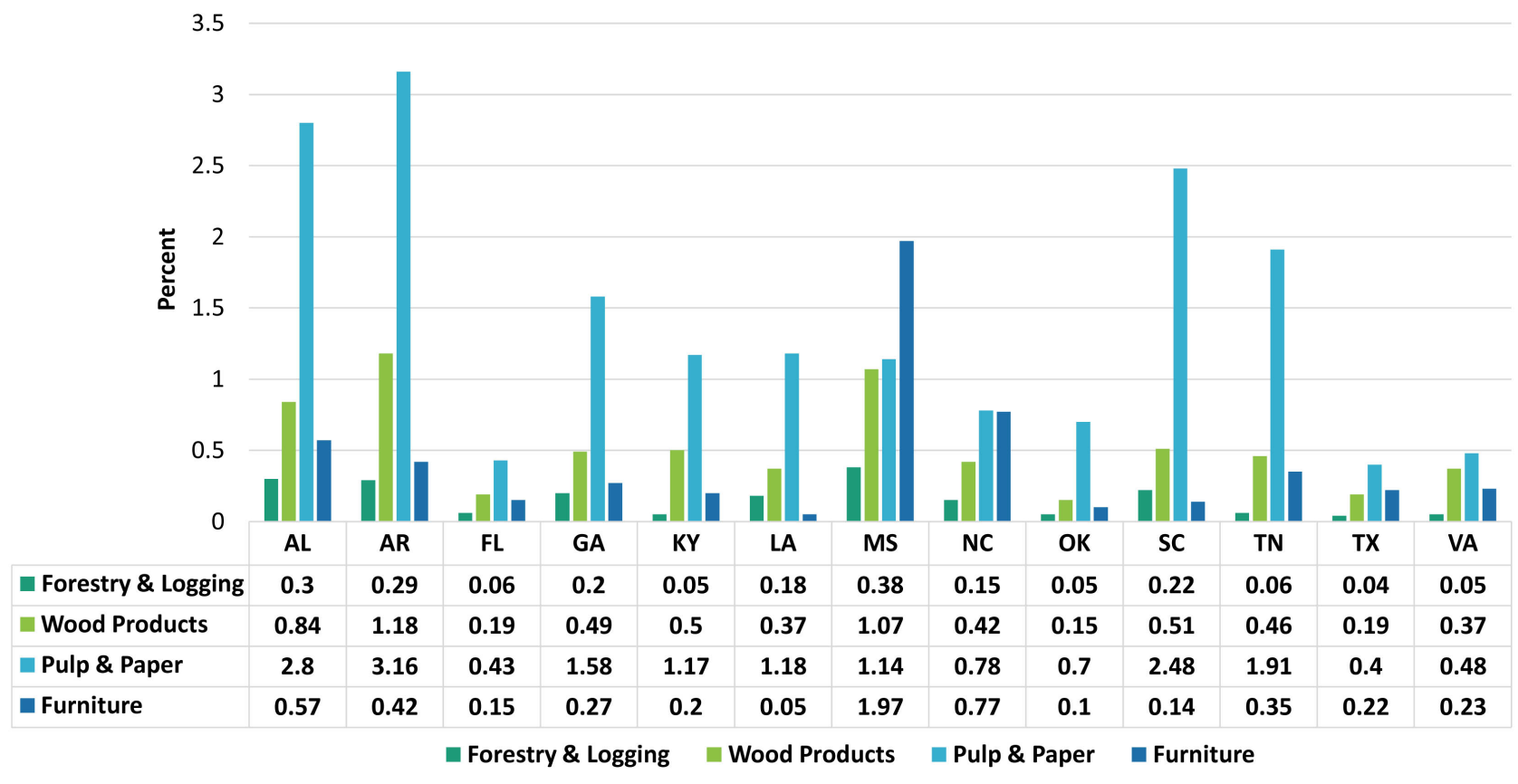

Figure 7. Percentage of total value added contributed by the forest sector to the southern states gross regional product, 2011 (Brandeis \& Hodges, 2015).

billion cubic feet in the South would be $\$ 1.62$ billion, and softwood price for 5.3 billion cubic feet would be $\$ 3.18$ billion.

\subsection{Nontimber Forest Products and Ecosystem Services}

Forests also provide nontimber forest products and economic contributions that receive payments directly for the products or to service providers who facilitate the activities. These include hunting and fishing of game; viewing of wildlife; and watching of local and migratory birds. Tourism and recreation such as canoeing, eco/tourism, and beach recreation and shore protection generate large incomes. Educational forest uses for elementary to secondary schools, youth groups, environmental education, and citizen science efforts also generate forest-based expenditures. In addition, payments for ecosystem services occur when government regulation creates markets, or if voluntary corporate efforts occur to promote environmental protection, such as for water quality, wetlands, and endangered species. There are large economic benefits of these and other ecosystem services that do not receive any direct payments, which could be estimated using nonmarket valuation techniques, but are not addressed here.

The National Report on Sustainable Forests (USDA Forest Service, 2011) provides national estimates of the value of nonwood forest products produced or collected in the U.S. (Table 4) and for Revenue from Forest-based Environmental Services in the U.S. (Table 5). The total value of U.S. nonwood forest products was $\$ 394$ million in 2007 and $\$ 361$ million in 2012. The data on nonwood products represents only data from USDA Forest Service (2018b) and USDI Bureau of Land Management direct sales, not other federal or private lands. The 
Table 4. Value of Nonwood forest products produced or collected in U.S. at point of first sale.

\begin{tabular}{ccc}
\hline Product & Value, 2007 (\$ million) & Value, 2012 (\$ million) \\
\hline Landscaping & 10 & 3 \\
Crafts/flora & 94 & 52 \\
Seeds/cones & 1 & 2 \\
Edible fruits, nuts, sap & 19 & 25 \\
Grass, forage & 12 & 9 \\
Herbs/medicinals & 1 & 2 \\
Subtotal & 137 & 93 \\
Fuelwood & 176 & 207 \\
Posts and poles & 12 & 11 \\
Christmas trees & 61 & 50 \\
Other & 7 & 0 \\
Total & 394 & 361 \\
\hline
\end{tabular}

Source: USDA Forest Service (2011, 2018b) National Report on Sustainable Forests 2011 (updated), 2018.

Table 5. Revenue from forest-based environmental services in the U.S.

\begin{tabular}{ccc}
\hline Product & Value, 2007 (\$ million) & Value, 2012 (\$ million) \\
\hline Government payments & 366 & 588 \\
Wetland mitigation banks & 727 & 446 \\
Hunting leases and entrance fees & 410 & 789 \\
Conservation easements & 315 & 199 \\
Conservation banks & 34 & 52 \\
Wildlife viewing & 34 & 71 \\
Carbon offsets & 1.7 & 7 \\
Subtotal, Non-Government & 1521 & 1566 \\
TOTAL, ALL & 1887 & 2166 \\
\hline
\end{tabular}

Source: USDA Forest Service National Report (2011, 2018b) on Sustainable Forests 2011 (updated), 2018

nonwood values are those for sales at the point of first sale-not as the stumpage equivalent in the woods-and perhaps more like delivered to mill wood prices.

The total revenue of U.S. forest-based environmental services was $\$ 1.9$ billion in 2007 and $\$ 2.2$ billion in 2012. This increased somewhat from 2007. It was comprised of $\$ 588$ million in government payments for conservation, and $\$ 1566$ million from market based payments. Thus the $\$ 361$ million value of U.S. nonwood forest products on the federal lands plus the total revenue of U.S. forest-based environmental services totaled \$2527 million. 


\subsection{Timber versus Nontimber Prices Plus Ecosystem Payments}

Southern forests comprise about $40 \%$ of U.S. total forests; bottomland forest areas are about $15 \%$ of southern forests; and bottomland forest harvests are about $9.55 \%$ of southern forests. The harvest of nonwood forest products is likely to follow this proportional share, as are the payments for environmental services. These statistics can be used to compute rough total values for economic payments, as summarized in Table 6.

The data in Table 6 provide a fascinating snapshot of approximate values of timber, forest products, nontimber, and ecosystem service payments in the U.S and the South. All southern forest products shipments in 2006 were valued at $\$ 160$ billion, and relative bottomland forest share of these based on their timber harvest would be $\$ 16$ billion. The value added-the best estimate of a sector's share of the total regional gross product that does not double count any input costs-would be $\$ 43$ billion for forest products, and $\$ 4.3$ billion for the bottomland hardwood contribution to that total.

The value of the annual timber harvest in the United States was calculated as $\$ 7.7$ billion; the South's would be $\$ 4.8$ billion, and the bottomland hardwood share $\$ 455$ million. This could be compared with nonwood forest products prices for the U.S. of \$361 million; \$144 million for the South, and \$25 million for

Table 6. Summary of comparative estimated national and southern forest values for timber, nontimber, and ecosystem service payments.

\begin{tabular}{|c|c|c|c|}
\hline Characteristic & $\begin{array}{l}\text { National } \\
\text { Value } \\
\text { (\$million) }\end{array}$ & $\begin{array}{l}\text { Southern } \\
\text { Share of } \\
\text { Value } \\
\text { (\$ million) }\end{array}$ & $\begin{array}{c}\text { Southern } \\
\text { Bottomland } \\
\text { Hardwood } \\
\text { Share (\$million) }\end{array}$ \\
\hline All Forest Products Shipments, 2006 & 320,522 & 160,000 & 16,000 \\
\hline Total Forest Products Value Added, 2006 & 92,800 & 43,000 & 4300 \\
\hline $\begin{array}{c}\text { Annual Hardwood Timber Removals, } \\
\text { Stumpage Value } 2011\end{array}$ & 2700 & 1620 & 455 \\
\hline $\begin{array}{c}\text { Annual Softwood Timber Removals, } \\
\text { Stumpage Value } 2011\end{array}$ & 4980 & 3180 & 0 \\
\hline $\begin{array}{c}\text { Annual Total Timber Removals, } \\
\text { Stumpage Value } 2011\end{array}$ & 7740 & 4800 & 455 \\
\hline Nonwood Forest Products, 2012 & 361 & 144 & 25 \\
\hline Ecosystem Service Payments, 2012 & 2166 & 866 & 153 \\
\hline Total, Nonwood and Ecosystem & 2527 & 1010 & 178 \\
\hline
\end{tabular}

Notes: Forest products shipments and value added from Forest2Market (2016), Brandeis \& Hodges (2015) and Dahal et al. (2015). 2011 national timber removals (harvests) were 8.3 billion $\mathrm{ft}^{3}$ of softwood; 4.5 billion $\mathrm{ft}^{3}$ of hardwoods; 12.9 billion $\mathrm{ft}^{3}$ total. Southern timber removals (harvests) were 5.3 billion $\mathrm{ft}^{3}$ of softwood; 2.7 billion $\mathrm{ft}^{3}$ of hardwoods; 8.0 billion $\mathrm{ft}^{3}$ total (Oswalt et al., 2014). Timber values calculated as mix of $50 \%$ sawtimber and $50 \%$ pulpwood, at a blended price of $\$ 0.60$ per cubic foot for stumpage for both softwood and hardwood species groups (Timber Mart-South, 2016). Southern timber land was $40 \%$ of U.S. timber land (Oswalt et al., 2014). Wetland harvest and value added $=10 \%$ of South harvest total based on bottomland hardwood volume share. Southern wetland nontimber and environmental services at $17.7 \%$ of southern forests based on area share, calculated by Sheffield 2016, or 7\% of all U.S. timber lands. 
bottomland hardwoods. United States ecosystem service payments in 2007 were $\$ 2.2$ billion; the southern share of payments $\$ 866$ million, and southern bottomland hardwood share of $\$ 153$ million.

Thus total U.S. nonwood products and ecosystem service payments were actually reasonably large compared to timber stumpage prices, at about one-third of the total national timber stumpage values, and $38 \%$ of the bottomland hardwood timber stumpage values. As a share of total value, nonwood products would comprise about $25 \%$ of all forest revenues, and $28 \%$ of bottomland hardwood revenues. The proportional value shares assume that nonwood forest products and ecosystem service payments are distributed proportionately across the U.S. regions and bottomland hardwood forest management type. There would be less proportional values for some items such as say wetland banks, which one would assume to be more prevalent in wetlands, but these might be offset by higher shares of goods such as Christmas trees from mountain or at least Piedmont physiographic regions, so making item by item adjustments to the broad nontimber products and ecosystem payments seems untenable.

\section{Discussion and Conclusions}

This review provides a summary of wetland forest areas, values, and economic contributions in the South. Obtaining universally agreed on data on wetland areas in the South is difficult, because the federal definition of wetlands has been fluid over time, and even if it were agreed on widely, one still needs to go to the field to determine whether a specific site and piece of property is indeed a wetland. Thus the aggregate data sources from the FIA, NRI, and NLCD provide only approximate estimates of wetland areas, based on remote sensing, field samples, and aggregation of the state estimates to the entire South as a region. However, once reconciled for the different public or private land areas that they cover, the total forest wetland area estimates for the U.S. South are relatively similar.

Of the three data sources that we examined, FIA and NRI both estimate that there are about 14.6 million ha (36 million acres) of forest wetlands in the southern states from Texas to Virginia. NRI only includes private land ownership, and FIA includes maybe up to $13 \%$ in public land, so the FIA data reported here provide the lowest wetland area estimates. The NLCD has a larger estimate of 15.8 million ha to 17.8 million ha of land cover called forest wetland, so is more generous in labeling forests as wetland.

It is not clear which of the three data sources is the most accurate, especially since the definition of wetlands under continual debate. The FIA and NRI data are the most consistent, with an estimate of about 14.6 million ha of forested wetlands in the South. However, the NRI and NLCD data appear to be more consistent in the relative wetlands areas among southern states, including more areas of wetlands in the east coast states. Thus we could conclude the higher NLCD estimate of at least 16 million ha for all private and public lands is possi- 
ble as well, and not much different than FIA or NRI.

Of the data sets, the USDA FS FIA site characteristics indicate that wetlands types would be about $17.7 \%$ of timber land, including 4.25 million ha of hydric sites, 0.77 million ha mesic wet, and 9.55 million ha mesic, seasonal access, for 14.6 million ha in total. These FIA wetland breakdowns by Forest Management Type would be 9.4 million ha bottomland hardwood; 1.7 million ha upland hardwood; 1.0 million ha oak-pine; 1.1 million ha natural pine; and 1.3 million ha pine plantation.

The literature on the aggregate economic contributions of the forest products industry-forests, timber production, and processing of solid wood, wood furniture, and paper products-provided substantial estimates in terms of actual people and dollars involved, but it was still a relatively small share of the total southern economy. Quite simply, all modern economies are broad and complex, with many important sectors, so no one sector can dominate most regions. Forest products based employment was 470,000 persons, equal to $0.84 \%$ of South Total. Gross output was $\$ 133$ billion, consisting of $1.62 \%$ of South Total. Wages and salaries were $\$ 26$ billion; $0.96 \%$ of the South Total. And the total value added of $\$ 43$ billion was $0.98 \%$ South Total. However, in several states, forest products accounted for up to $5 \%$ of the state economy, and was the largest contributor to value added in many southern states.

Based on the FIA data, one can derive the share of wetland forests as a component of total forest products economy, nontimber goods, and ecosystem services. Bottomland hardwood timber land consists of 12.6 million ha- $15 \%$ of the South, although not all of these are wetlands. However, the addition of other forest management types increases the estimated hydric and mesic wet forest areas of the South to 14.6 million ha, which is about equal to the NRI estimate of southern wetlands, and equals $17.7 \%$ of all southern timber land.

Timber removal volumes based on the FIA data were less on southern hardwood forests (34\%) and on bottomland hardwoods ( $28 \%$ of all hardwoods) than on pine types $(66 \%)$, so we estimate that at least $9.5 \%$ of the total southern timber harvest volume is obtained from wetlands given the 12.6 million ha of bottomland hardwood types, and this estimate would increase to more than $10 \%$ with the additions of 2 million ha in the other forest management types. In practice, only 9.4 million ha of bottomland hardwoods are classed as wetlands, and 5.2 million ha of other forest management types make up the difference for the 14.6 million ha wetland total of all FIA forest management types. This would increase the wetland timber harvests to slightly more than $10 \%$ of the total. These derivations then indicate that at least $10 \%$ of the southern timber-based forest products economy is derived from wetland forests based on the value of its harvests, while almost $18 \%$ of the southern nontimber forest products and payments for ecosystem services stem from wetland forests based on the share of area that they include.

The relative values of timber stumpage of $\$ 455$ million from wetland forests versus $\$ 178$ million for nontimber products and payments for ecosystem servic- 
es also are interesting. Stumpage values are 2.7 times greater than payments from nontimber and ecosystem values for wetland forests. The differences would be 4.8 times greater for all southern forests, where southern pine timber harvest (and values) are far greater, and nontimber/ecosystem values only increase moderately. Total nonwood and ecosystem values then would comprise about $28 \%$ of all southern wetland incomes generated each year, and about $25 \%$ of all national forest incomes. These differences between timber and nontimber values are not as large as one might expect.

There are also much greater values that have been estimated for the nonmarket benefits of ecosystem services, in addition to the direct payments reported here. These include benefits such as watershed and soil protection, water filtering, climate control, carbon storage, nutrient cycling, soil formation, biodiversity, rare habitats, landscape, corridors, recreation, aesthetic, cultural, and spiritual values. Nonmarket valuation tries to estimate these environmental and social values, using revealed preference approaches such travel costs, hedonic pricing, ecosystem production and cost functions; or using stated preferences methods such as contingent valuation method (CVM), stated choice, or conjoint analysis; or by benefits transfer methods (Sills et al., 2017).

Some studies have examined the nonmarket values of forested wetlands, and indeed provided quite large theoretical prices for forest wetlands. For example, Jenkins et al. (2011) estimated the economic effects of Wetlands Reserve Program using site and region level measurements and ecosystem process models. They found that greenhouse gas mitigation was worth $\$ 171$ to $\$ 222$ per ha per year; nitrogen fixation was worth $\$ 1486$ per ha per year; waterfowl recreation was worth $\$ 16$ per ha per year. These values were contrasted with the land value of conventional timber management, which had actual values of only about $\$ 70$ per ha per year. Of course, the timber benefits could be received as cash payments, and ecosystem benefits were social values, not cash. Moore et al. (2011; cited in Mahaffey \& Evans 2016) estimated that forested wetlands had annual values of $\$ 11,600$ per ha for flood control, $\$ 8600$ per ha for pollution treatment, and $\$ 2850$ per ha for water supply value in Georgia.

The preceding two large estimates of southern wetlands values in the refereed and gray literature, respectively, are promising, but still do not mean that those values will result in commensurate direct payments to landowners in the foreseeable future. Thus in this paper, we focused on comparing the specific market transactions-either through private markets or government payments-to compare the actual wetland economy in the South. Timber income from stumpage sales in southern bottomland forests provided the largest cash receipts as calculated here. These incomes calculated were followed by the direct government or market payments received for environmental services, at about $30 \%$ of the calculated timber income. Nontimber forest products sales were less, at about $10 \%$ of the estimated timber receipts. Wetland forests also provide a wealth of nonmarket, non-paid ecosystem services, which have ecological and social values, but have not been monetized to date. They may indeed be far 
greater than those market price measurements tallied and estimated here.

The potential large areas and high values of wetlands are indeed the premise on which much of the Clean Water Act protection for wetlands is based. This paper does provide a review of current forest wetland areas and market values in the South. This should be useful in clarifying forest wetland areas and values for the region, and providing much better information for assessing trends and for discussing wetland forest policy options in the future.

\section{Conflicts of Interest}

The authors declare no conflicts of interest regarding the publication of this paper.

\section{References}

Brandeis, C., \& Hodges, D. G. (2015). Forest Sector and Primary Forest Products Industry Contributions to the Economies of the Southern States: 2011 Update. Journal of Forestry, 113, 205-209. https://doi.org/10.5849/jof.14-054

Cubbage, F. W., \& Flather, C. H. (1993). Forested Wetland Area and Trends. Journal of Forestry, 91, 48-54.

Cubbage, F. W., O’Laughlin, J., \& Peterson, M. N. (2017). Natural Resource Policy (509 p.). Long Grove, IL: Waveland Press.

Dahal, R. P., Henderson, J. E., \& Munn, I. A. (2015). Forest Products Industry Size and Economic Multipliers in the U.S. South. Forest Products Journal, 65, 372-380. https://doi.org/10.13073/FPJ-D-14-00083

Forest2Market (2016). The Economic Impact of Privately-Owned Forests in the United States.

http://forestryimpacts.net/reports/southern-region/Forest2Market_Economic_Impact_ of_Privately-Owned_Forests_April_2016.pdf

Homer, C., Dewitz, J., Yang, L., Jin, S., Danielson, P., Xian, G., Coulston, J., Herold, N., Wickham, J., \& Megown, K. (2015). Completion of the 2011 National Land Cover Database for the Conterminous United States-Representing a Decade of Land Cover Change Information. Photogrammetric Engineering and Remote Sensing, 81, 345-354.

Jenkins, W. A., Murray, B. C., Kramer, R. A., \& Faulkner, S. P. (2011). Valuing Ecosystem Services from Wetlands Restoration in the Mississippi Alluvial Valley. Ecological Economics, 69, 1051-1061.

Mahaffey, A., \& Evans, A. (2016). Ecological Forestry Practices for Bottomland Hardwood Forests of the Southeastern U.S. Forest Stewards Guild (44 p.).

Moore, R., Williams, T., Rodriguez, E., \& Hepinstall-Cymmerman, J. (2011). Quantifying the Value of Non-Timber Ecosystem Services from Georgia's Private Forests. Forsyth, GA: Georgia Forestry Commission.

Oswalt, S. N., Smith, W. B., Miles, P. D., \& Pugh, S. A. (2014). Forest Resources of the United States, 2012: A Technical Document Supporting the Forest Service Update of the 2010 RPA Assessment. General Technical Report 91, Washington Office, USDA Forest Service. http://www.srs.fs.usda.gov/pubs/gtr/gtr_wo091.pdf

Sills, E. O., Moore, S. E., Cubbage, F. W., McCarter, K. D., Holmes, T. P., \& Mercer, D. E. (2017). Trees at Work: Economic Accounting for Forest Ecosystem Services in the U.S. South (117 p.). Asheville, NC: U.S. Department of Agriculture Forest Service General 
Technical Report SRS-226, Southern Research Station.

Timber Mart-South (2016). South-Wide Timber Stumpage Prices. Athens: University of Georgia Center for Forest Business Management.

Tiner, T. W. (2016). Wetland Indicators: A Guide to Wetland Formation, Identification, Delineation, Classification, and Mapping (2nd ed.). Boca Raton, London, New York, NY: CRC Press. https://doi.org/10.1201/9781315374710

USDA Forest Service (2011). National Report on Sustainable Forests-2010 United States Department of Agriculture Forest Service. FS-979, Washington DC.

USDA Forest Service (2018a). Forest Inventory and Analysis Glossary. United States Department of Agriculture Forest Service.

https://www.nrs.fs.fed.us/fia/data-tools/state-reports/glossary/default.asp

USDA Forest Service (2018b). National Report on Sustainable Forests-2015. United States Department of Agriculture Forest Service. (In Press)

\section{Abbreviations}

ac: acres

CWA: U.S. Clean Water Act of 1977

CVM: Contingent valuation Method

FIA: U.S. Department of Agriculture Forest Service Forest Inventory and Analysis (FIA) Data

FWPCA: U.S. Federal Water Pollution Control Act (FWPCA) Amendments of 1972

ha: hectares

NLCD: U.S. Department of Interior Geological Survey National Land Cover Data

NRI: U.S. Department of Agriculture Natural Resource Inventory (NRI)

USDA: U.S. Department of Agriculture 